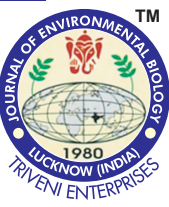

\title{
Plant-assisted remediation of wastewater contaminated with methyl orange using Scirpus grossus
}

\section{Authors Info}

E.A. Almaamary ${ }^{1 *}$, S.R.S.

Abdullah', H.A. Hasan', N.I. Ismail', R.A. Ab. Rahim ${ }^{1}$ and M. Idris ${ }^{2}$

${ }^{1}$ Department of Chemical and Process Engineering, Faculty of Engineering and Built Environment, Universiti Kebangsaan Malaysia, Selangor, 43600, Malaysia

${ }^{2}$ Tasik Chini Research Centre, Faculty of Science and Technology, Universiti Kebangsaan Malaysia, Selangor, 43600, Malaysia

\section{*Corresponding Author Email :} enas.phd@gmail.com

\section{Edited by}

Prof. Muhammad Aqeel Ashraf

\section{Reviewed by}

Dr. Keqing Li

Dr. Dan Li

\begin{abstract}
Aim: This study explores the possibility of treating basic dye, methyl orange using Scirpus grossus in a batch free flow surface system.

Methodology: The effect of operational parameters ( $\mathrm{pH}, \mathrm{ORP}, \mathrm{ABS}, \mathrm{BOD}, \mathrm{COD}$ and TOC) for different dye concentrations $\left(0,200,400,600,800\right.$ and $\left.1000 \mathrm{mg} \mathrm{l}^{-1}\right)$ were observed and determined during 42 days. The results of UV-Vis absorption, HPLC and GC-MS confirmed the degradation of methyl orange.

Results: The removal efficiency of methyl orange dye from synthetic wastewater ranged between 15-64\% for all treatments at different $r$ concentrations between $1000-200 \mathrm{mg} \mathrm{l}^{-1}$, respectively. Moreover, the highest removal for BOD and COD in $400 \mathrm{mg} \mathrm{l}^{-1}$ and TOC in $200 \mathrm{mg} \mathrm{l}^{-1}$ methyl orange were 55, 52 and $42 \%$, respectively. Four metabolites after the degradation of dye were identified as 4-tert-butylcyclohexanone, 1 , 4-dimethylbenzen, N, N-dimethyl hydrazine, 1, 4, 7, 10, 13-pentaoxacyclopentadecane using GC/MS.
\end{abstract}

Interpretation: Scirpus grossus is capable to phytoremediate dyes in wastewater.

Keywords: Decolorization; Methyl orange; Phytoremediation; Scirpus grossus, Textile industry

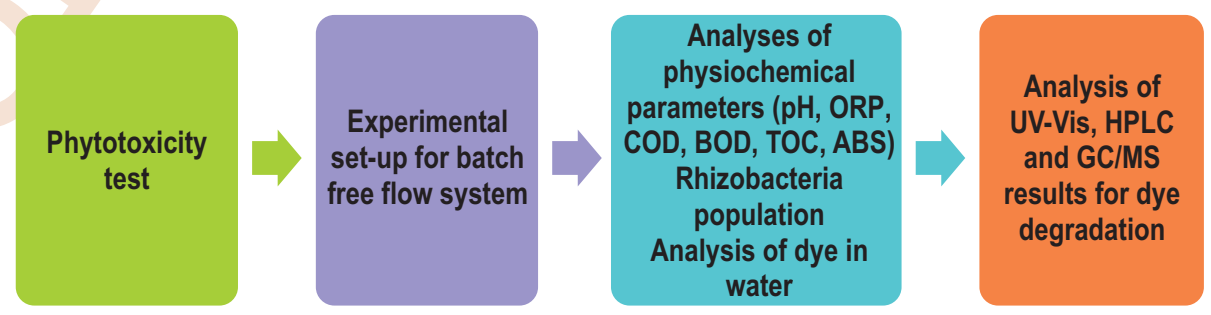

Citation: Almaamary, E.A., S.R.S. Abdullah, H.A. Hasan, R.A. Ab. Rahim and M. Idris: Plant-assisted remediation of wastewater contaminated with methyl orange using Scirpus grossus. J. Environ. Biol., 40, 515-523 (2019). 


\section{Introduction}

The increase in textile industries has led to accumulation of large amount of xenobiotic compounds that contaminate the environment and natural resources. In textile, leather, plastic, cosmetic, and food industries different azo dyes are used .Azo dyes represent the most common group of synthetic dyes constituting $60-70 \%$ of more than 10,000 dyes used in textile industry. The effluents of textile industries are characterized by high content of chemical oxygen demand, total organic carbon, biological oxygen demand, total suspended solids and high $\mathrm{pH}$ (acidic or alkaline). Distortion of water quality in the natural ecosystem has urged for proper treatment of industrial wastewater for environmental protection. Various techniques like adsorption, coagulation, ozonation and electrolysis and advanced oxidation processes such as $\mathrm{TiO}_{2}$-mediated photocatalytic oxidation and activated carbon are being used for purification and decolourization of dye wastewater. However, all these chemical treatment technologies are costly and always end-up with high maintenance cost.

Phytoremediation or plant-assisted remediation is a green technology that use plants for remediation of contaminated sites. Plants contain enzymatic mechanism to break down and degrade complex structures and can be used for cleaning the contaminated sites. It is an environmentally sound and sustainable technology for cleaning contaminated sites. Khandare and Govindwar (2015) extensively reviewed the possibility of applying phytoremediation in treating effluents from textile industries. This plant-assisted remediation technology is also applied to remediate wastewater containing heavy metals (Barman and Datta 2018; Selamat et al., 2018; Ismail et al., 2017) and organic pollutants (Al-Baldawi et al., 2017; Almansoory et al., 2017; Sanusi et al., 2017; Al-Sbani et al., 2016).Integration of phytoremediation and mycoremediation was also investigated by Mandal and Das (2018) to treat benzo[a]pyrene in soil. A previous study by Rane and Chandanshive (2014) has reported potential of Rheum rabarbarum and Blumea malcomi in remediation of textile dyes. Kalgakar et al. (2010) successfully utilized Typhonium flagelliforme to degrade Brilliant Blue R., and Khandare et al. (2011) has conducted a study to degrade Navy Blue HE2Rusing Portulaca grandiflora Hook. While Al-Badawi et al. (2018) used Azzola pinnata to treat wastewater containing methylene blue. In this study, native plant of Scirpus grossus was used. S. grossus is indigenous to Malaysia and is locally known as Rumput menderong. S. grossus belongs to Cyperaceous family and is commonly known as giant bulrush. S. grossus is an aquatic plant with high growth rate and is often found growing in large colonies in water. Bulrushes are often seen as tall with leafless stems growing in profusion. The plants have sharp-tosoft stems, triangular leaves, and obvious leaf blades; the inflorescences always appear on stem tips in a tight cluster or spreading open with leaves resembling stems (UF/IFAS, 2007).
Plants possess enzymatic and uptake processes that can degrade organic pollutants or contain and stabilize contaminants by acting as filters or traps. The effective microorganisms are most important factors for biological treatment processes. For long time, researches mainly focused on bacteria and fungi. The emerging products such as some aromatic amines can be degraded by hydroxylase and oxygenase produced by bacteria .This study aims to explore the role of a native Malaysian plant, Scirpus grossus in a free flow system (FSF) operated batch wise to remove textile dyes containing methyl orange dye at different concentrations in synthetic wastewater with a prudence into the involvement of bacteria and confirmation of metabolic pathway behind degradation of dye. S. grossus is an aquatic species with a high growth rate and has the ability to degrade hydrocarbons , heavy metals, recycled paper mill and methylene blue.

\section{Materials and Methods}

The plants of Scirpus grossus were collected from Tasik Chini,Pahang, Malaysia. They were propagated by cutting the stems and leaving the roots inside tank with garden soil for one month before they were ready for use. This study was conducted in a greenhouse at Universiti Kebangsaan Malaysia and the phytotoxicity experiment utilized a batch free flow system.

Tank preparation: In this project, 21 aquariums made of glass, 15 of them were filled with wastewater contaminated with methyl orange dye and plants with three replicates (R1, R2, R3), together with an aquarium for the control contaminant without plants (CC), as well as three aquariums without methyl orange contaminant as plant controls (PC), as illustrated in Fig. 1(A). Twelve healthy plants of $S$. grossus were planted into each aquarium containing 13 I of wastewater filled by mixing methyl orange with water at different concentration $\left(200,400,600,800\right.$ and $\left.1000 \mathrm{mgl}^{-1}\right)$. Each aquarium with dimensions of $\mathrm{L} 30 \mathrm{~cm} \times W 30 \mathrm{~cm} \times D 30 \mathrm{~cm}$ was filled from the upper layer to the bottom layer with: (1) $10 \mathrm{~cm}$ depth of fine sand with $\phi=2 \mathrm{~mm}(2) 3 \mathrm{~cm}$ of gravel with a size of $\phi=1-5$ $\mathrm{mm}$ and (3) $8 \mathrm{~cm}$ of gravel with a size of $\Phi=10-20 \mathrm{~mm}$ (Fig. 1(B)).

The operational parameters were monitored during 42 days of exposure whereas samplings were carried out on day 0 , 7,28 , and 42 day. $\mathrm{pH}$, temperature, dissolved oxygen and oxidation reduction potential were recorded to observe the physico-chemical changes in water using a Metrohmmulti-probe (Model 877,Swiss) for $\mathrm{pH}, \mathrm{ORP}$ and temperature measurements. For dissolved oxygen, sensor (YSI, Model 550A, USA) was used.

Monitoring of water quality parameters: The BOD, COD and TOC of methyl orange contaminated water was measured. The spectrophotometer (DR3900 Hach, Germany) was used in this study to determine the COD and TOC values. The BOD value was determined by measuring dissolved oxygen levels for the sample before and after incubation for 5 days Winkler's iodometric method (Winkler, 1888). 


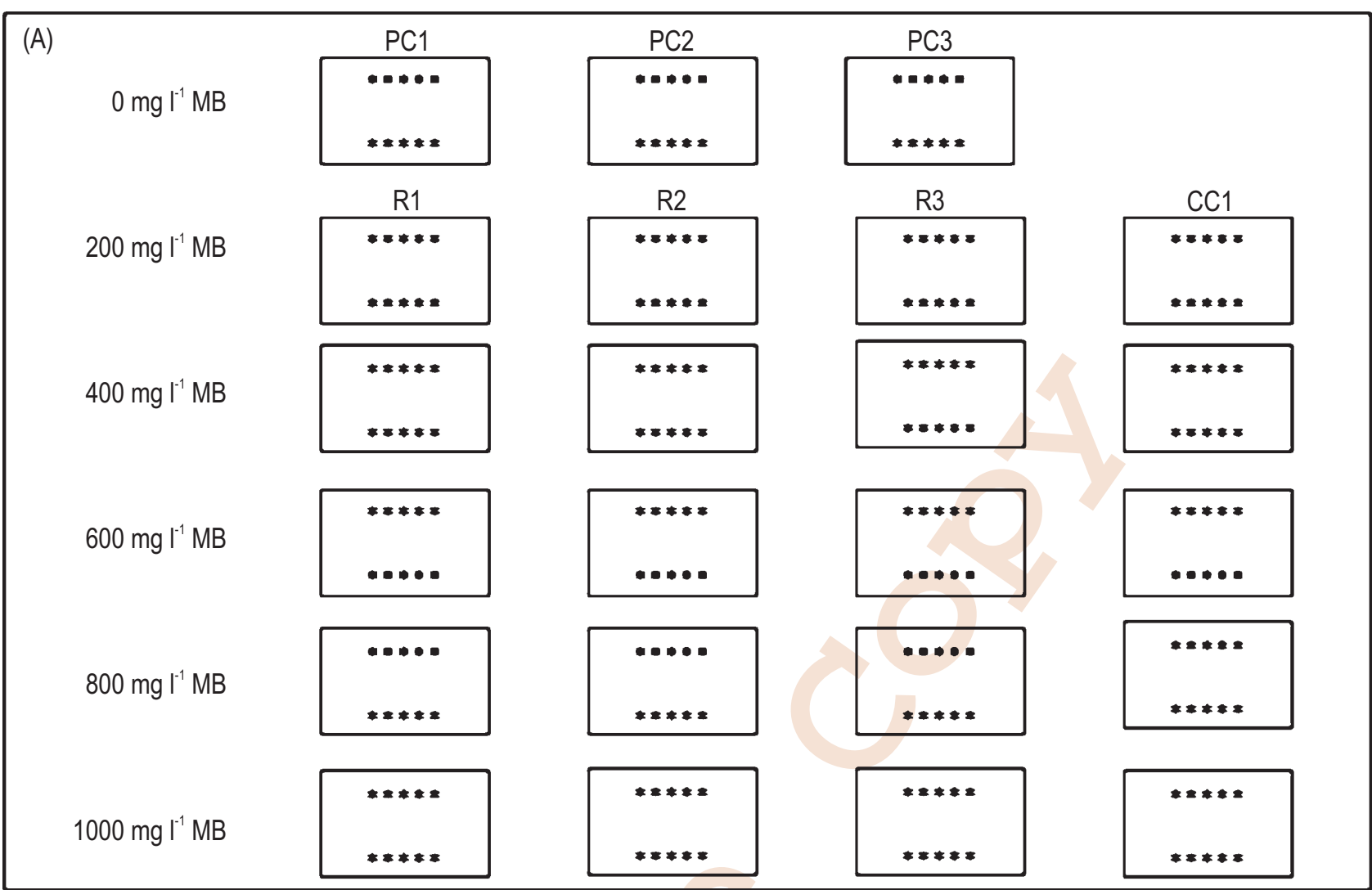

(B)
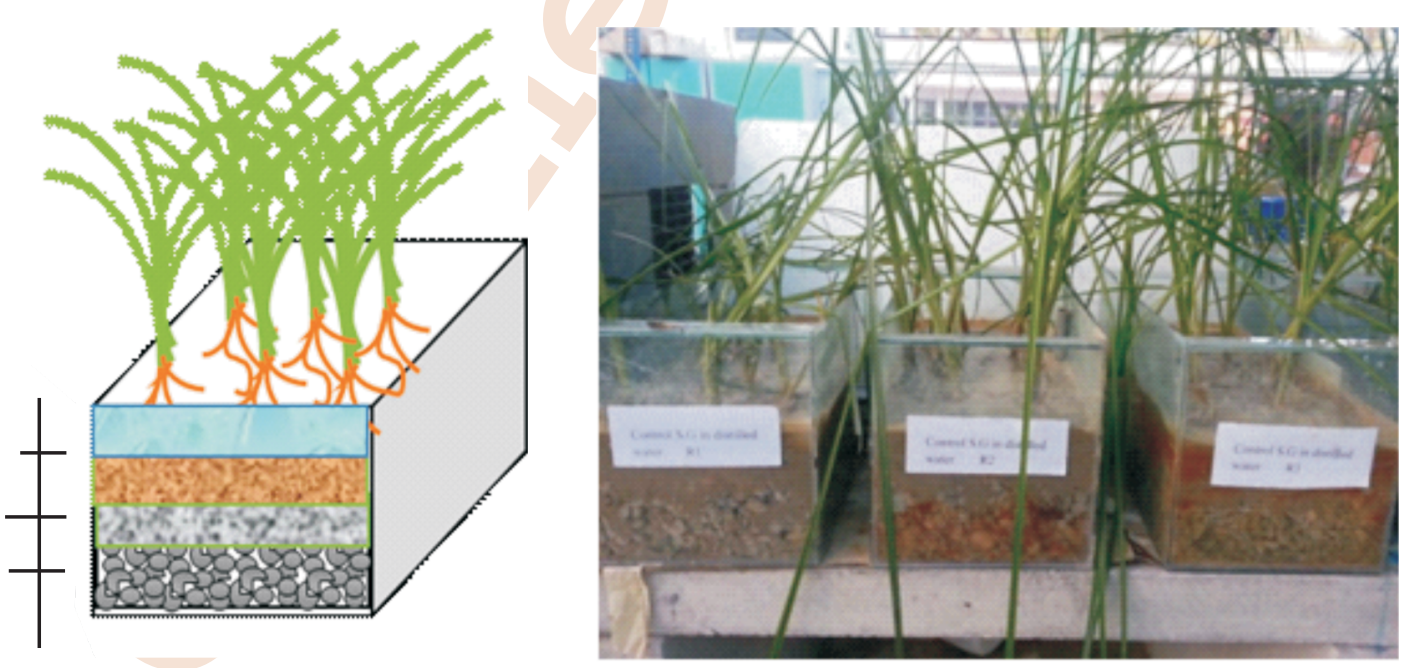

Fig. 1 : (A) Experimental set-up for phytotoxicity experiment with plant control $(\mathrm{PC})$, contaminant control $(\mathrm{CC})$ without plants and treatment with plants $(\mathrm{R} 1, \mathrm{R} 2, \mathrm{R} 3)$; (B) Aschematic diagram of an aquarium for removal of methyl orange.

Population of bacteria associated with plant roots: It was obtained from the roots and sand attached to the rhizosphere zone. A number of bacteria live in the roots of plants irrigated with dye contaminated water. The population of these bacteria was estimated through serial dilution method. At first, $10 \mathrm{~g}$ of plant roots were harvested and then put into $100 \mathrm{ml}$ of sterile distilled water to obtain a dilution of $10^{-2}$. This was shaken at $150 \mathrm{rpm}$ for 1 $\mathrm{hr}$ to release adhered microorganisms. After transferring 1-9 ml of sterile saline water, subsequent dilutions up to $10^{-4}$ were made. Next, $0.1 \mathrm{ml}$ of three dilution $\left(10^{-2}, 10^{-3}\right.$ and $\left.10^{-4}\right)$ was spread onto sterile plates containing nutrient agar medium (tryptic soya agar, TSA). The plates were incubated inverted at $37^{\circ} \mathrm{C}$ for $24 \mathrm{hr}$. Colonies of more than 20 and less than 300 cells were counted. The number of colonies counted was multiplied by the reciprocal 
of dilution and the amount plated, and the results were expressed as colony forming units (CFU ml ${ }^{-1}$ ) (Sieuwerts et al., 2008).

Analytical procedures for detection of biotransformation products: Decolorization of all dyes on each sampling day was monitored using UV-Vis spectroscopic analysis (DR 3900 $\mathrm{HACH}$ ) at $465 \mathrm{~nm}$. Decolourization percentage for methyl orange dye was determined by comparing the initial absorbance with the observed absorbance on each sampling day. In addition, phyto transformation was monitored using HPLC (WATERS 2695, Detector at $254 \mathrm{~nm}$ and column C 18,symmetry, $4.6 \mathrm{~mm} \times 250 \mathrm{~mm}$ by using gradient of methanol and acetonitrile (75:25) at a flow rate of $1 \mathrm{ml} \mathrm{min}^{-1}$ for $10 \mathrm{~min}$. Identification of metabolites produced was carried out using GC/MS. GC/MS 7890A gas chromatograph (GC) was directly coupled to the mass spectrometer system of an
Agilent 5975Cinert MSD with triple-axis detector. Chromatographic separation was achieved on a $30 \mathrm{~m}$ DB- $5 \mathrm{~ms}$ for non-polar. The column temperature program was $50^{\circ} \mathrm{C}$, held for $0.5 \mathrm{~min}, 10^{\circ} \mathrm{C} \mathrm{min}^{-1}$ to $200^{\circ} \mathrm{C}, 5^{\circ} \mathrm{C} \mathrm{min}{ }^{-1}$ to $235^{\circ} \mathrm{C}, 10^{\circ} \mathrm{C} \mathrm{min}$ to $280^{\circ} \mathrm{C}$ and held for $10 \mathrm{~min}$. The injector temperature was maintained at $250{ }^{\circ} \mathrm{C}$. Injection was performed in the split less mode using a split less time of 0.7 min with constant column flow of $1.0 \mathrm{ml} \mathrm{min}$. The capillary column was coupled directly to the ion source which was operated in electron impact ionization mode. The transfer line temperature was $300^{\circ} \mathrm{C}$.

\section{Results and Discussion}

The maximum decolorization (64\%) was obtained at 200 $\mathrm{mg} \mathrm{l}^{-1}$ and the minimum decolorization (15\%) was achieved at
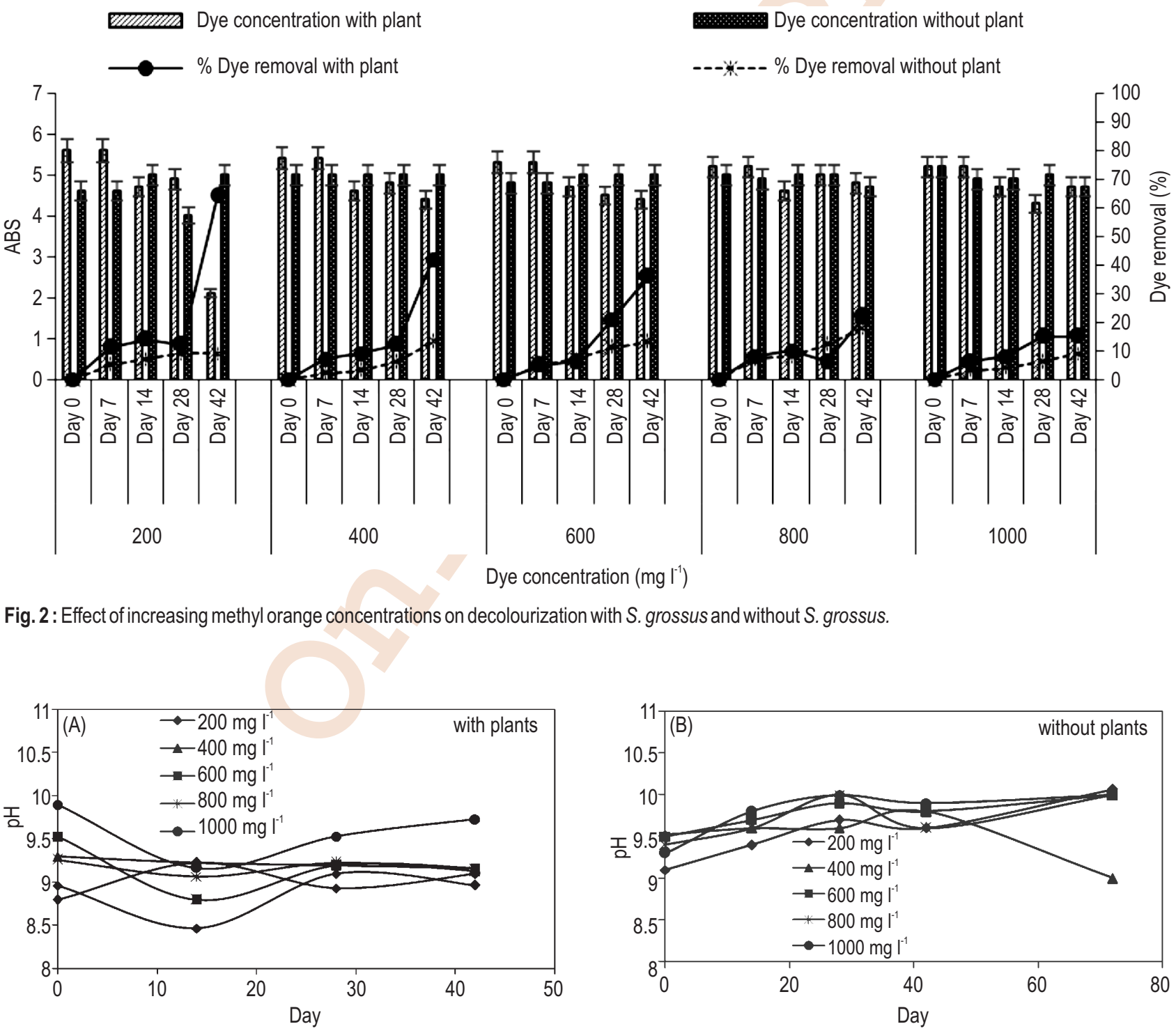

600

800

1000

ye concentration $\left(\mathrm{mg} \mathrm{l}^{-1}\right)$

Fig. 2 : Effect of increasing methyl orange concentrations on decolourization with S. grossus and without S. grossus.

Fig. 3: pH reading of $(\mathrm{A})$ with plants and $(\mathrm{B})$ without plants for 42 days.

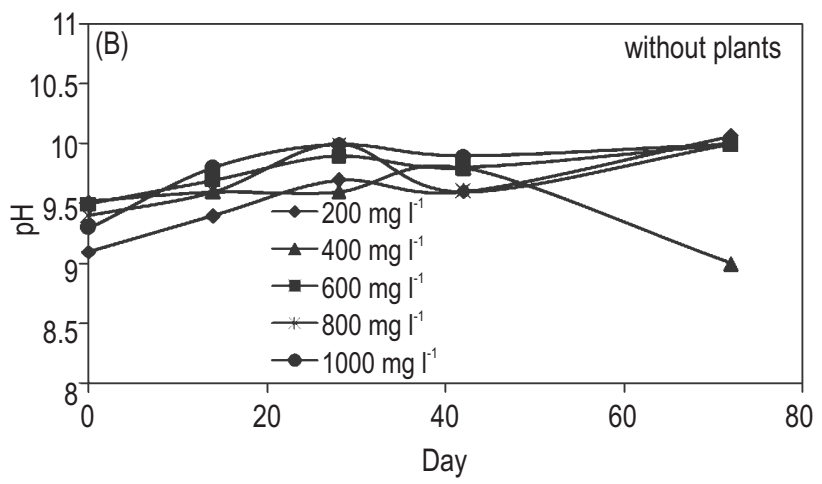



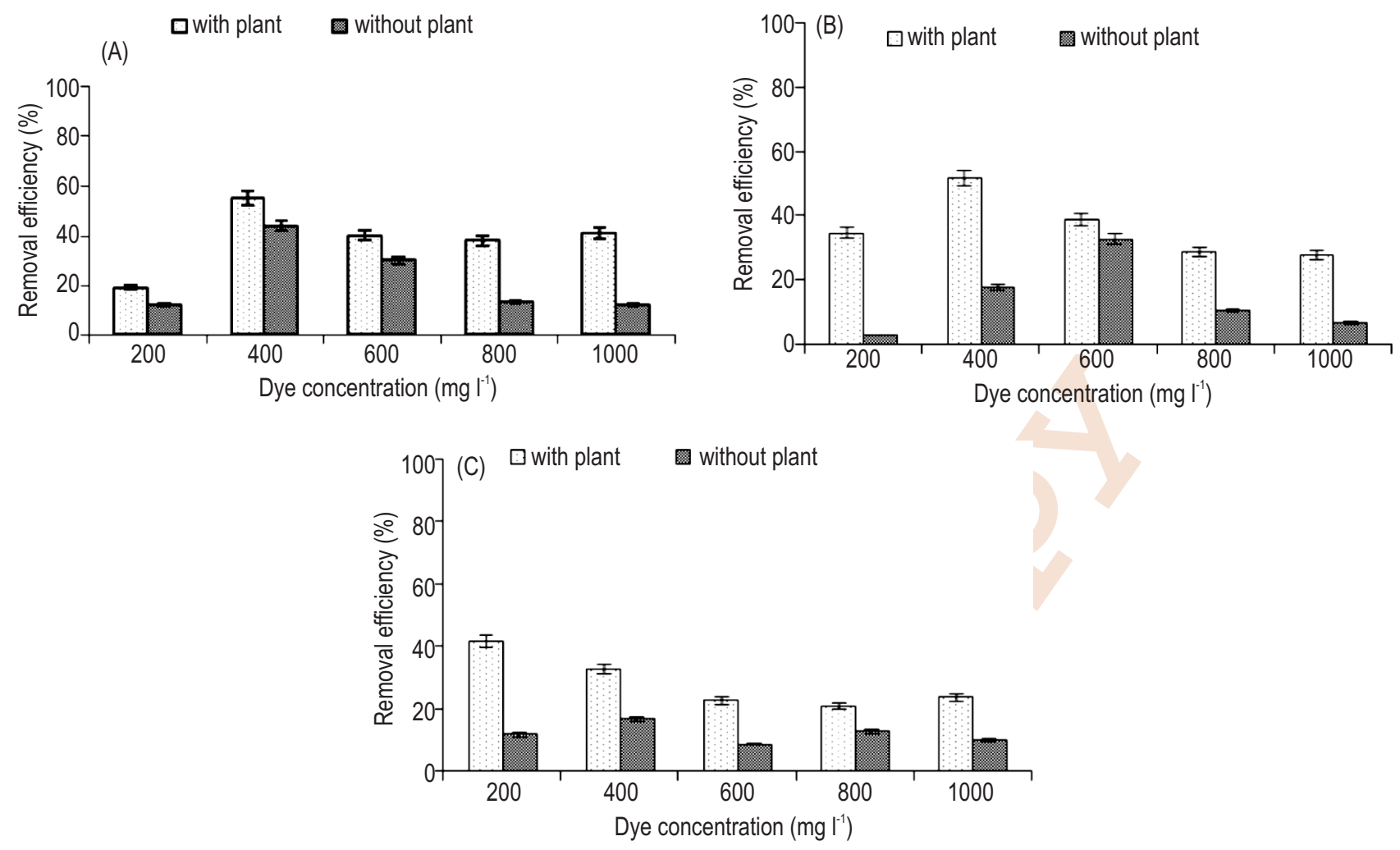

Fig. 4 : Percentage removal of (A) BOD, (B) COD and (C) TOC at different concentration of methyl orange.

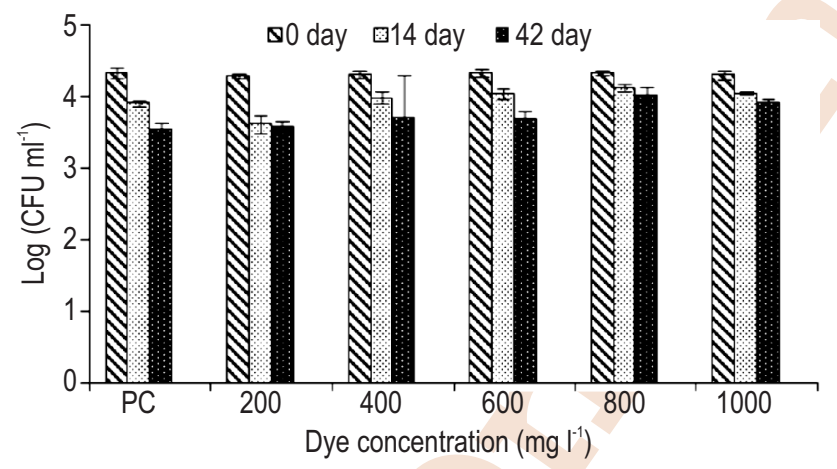

Fig. 5 : Total count of bacterial population during 42 days of experiment. Comparison of the microbial populations in the control $(\mathrm{PC})$ and with different $\mathrm{MO}$ concentrations.

$1000 \mathrm{mg} \mathrm{l}^{-1}$ throughout 42 day exposure. The methyl orange removal within the exposure days were 42,36 and $22 \%$ at 400,600 and $800 \mathrm{mg} \mathrm{l}^{-1}$,as illustrated in Fig. 2. The increasing methyl orange concentration decreased methyl orange decolorization throughout 42 days. On the other hand, for comparison with control aquaria without plants, decolorization of methyl orange was only $9 \%\left(200 \mathrm{mg} \mathrm{l}^{-1}\right), 13 \%\left(400 \mathrm{mg} \mathrm{l}^{-1}\right), 13 \%$ $\left(600 \mathrm{mg} \mathrm{l}^{-1}\right), 18 \%\left(800 \mathrm{mg} \mathrm{l}^{-1}\right)$ and $9 \%\left(1000 \mathrm{mg} \mathrm{l}^{-1}\right)$, respectively. This comparison with contaminant control confirms the ability of S. grossus to decolorize methyl orange dye. In another study, K. rosea was used to decolorized methyl orange dye. The time required for decolorization of methyl orange dye at 10, 30, 50, 70 and $100 \mathrm{mgl}^{-1}$ were $100 \%$ for $48 \mathrm{hr}, 100 \%$ for $60 \mathrm{hr}, 100 \%$ for $72 \mathrm{hr}$, $73 \%$ for $120 \mathrm{hr}$ and $40 \%$ for $120 \mathrm{hr}$ respectively (Chang and Kuo, 2000). Similarly Tan et al. (2016) reported $66.8 \%$ of colour remove methyl orange using Eichhornia crassipes.

The $\mathrm{pH}$ can affect the efficiency of colour removal. Fig. $3(\mathrm{~A}, \mathrm{~B})$ shows the $\mathrm{pH}$ readings of methyl orange for 42 days. The $\mathrm{pH}$ value of methyl orange with and without plant ranged during $\mathrm{pH}$ 8.5-10 experiment. The fluctuation of $\mathrm{pH}$ is due to free diffusion of carbon dioxide in the atmosphere and absorption of nutrient by the plants (Lin and Mendelssoohn, 2009).

The conditions of phytotoxicity test can be distinguished whether it is aerobic or anaerobic through DO and ORP measurement. A negative ORP indicates that a substance is in reducing state, lower the reading, more anti-oxidizing it is (Telke et al., 2011). The ORP reading ranged from -07 to $-53 \mathrm{mV}$ in this study. Methyl orange affected the environment of treatments around the rhizosphere and reduced the ORP readings, indicating that the environment was becoming more anaerobic with increasing methyl orange concentration.

The BOD, COD and TOC values of methyl orange dye at different concentrations decreased in the test samples treated 


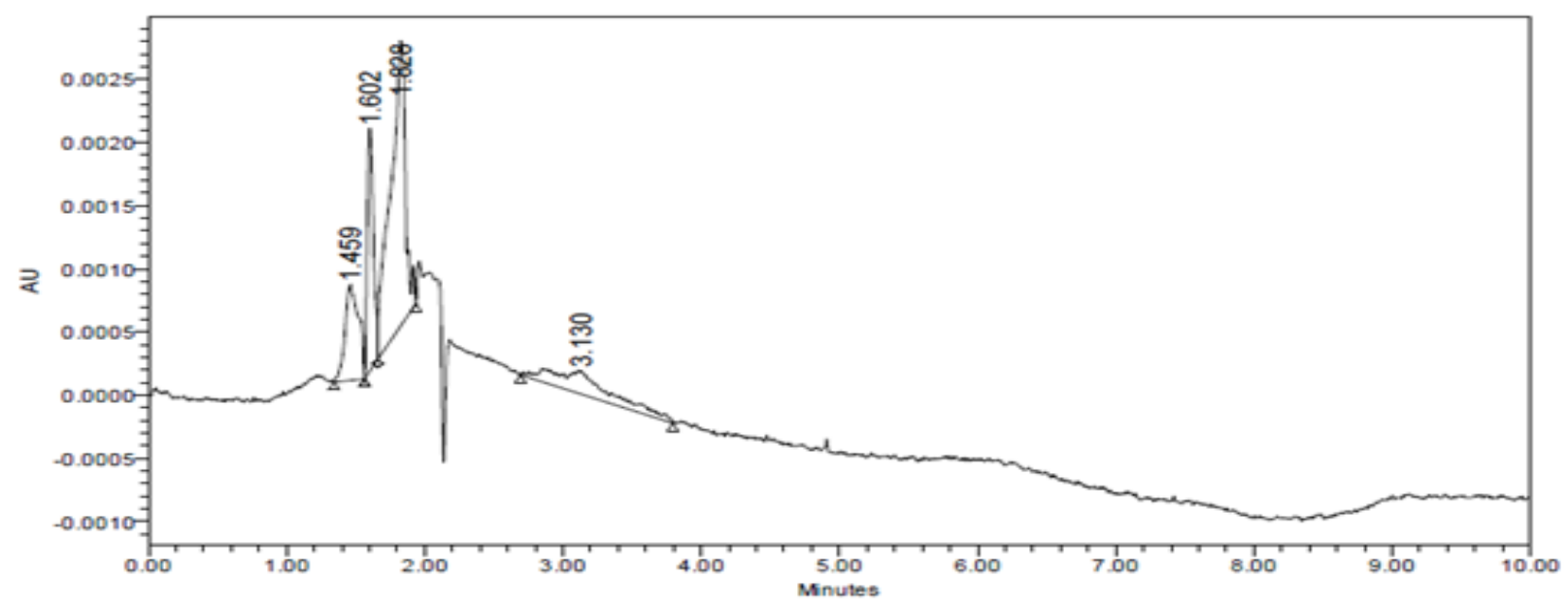

Fig. 6 (A) : Untreated methyl orange at $200 \mathrm{mgl}^{-1}$.

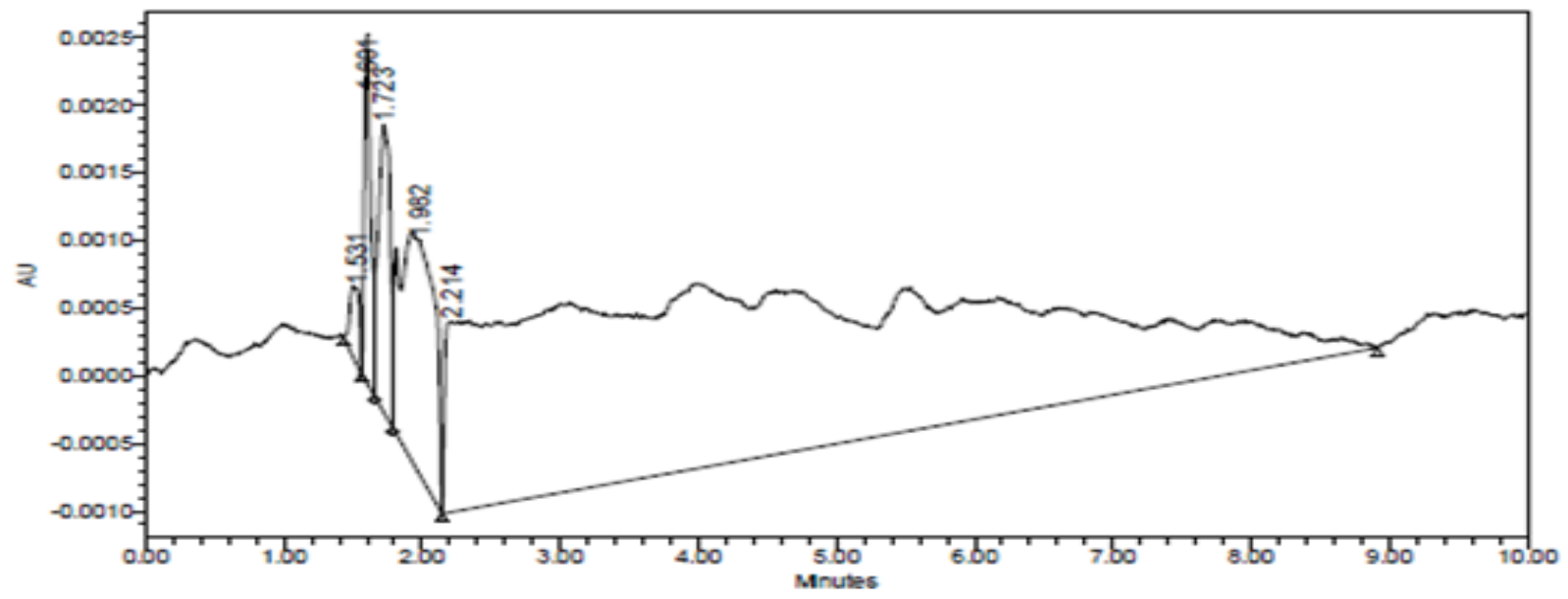

Fig. 6 (B) : Ttreated methy orange at $200 \mathrm{mgl}^{-1}$.

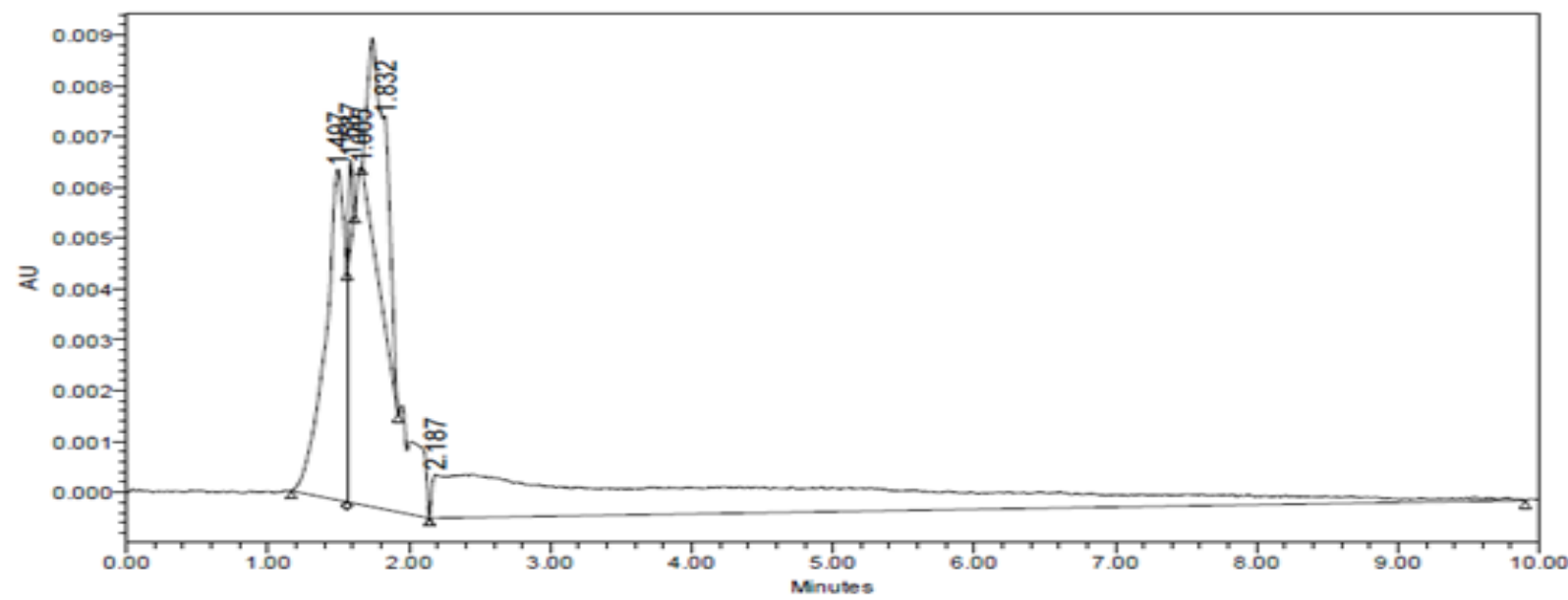

Fig. 6 (C): Untreated methyl orange at $1000 \mathrm{mg} \mathrm{l}^{-1}$. 


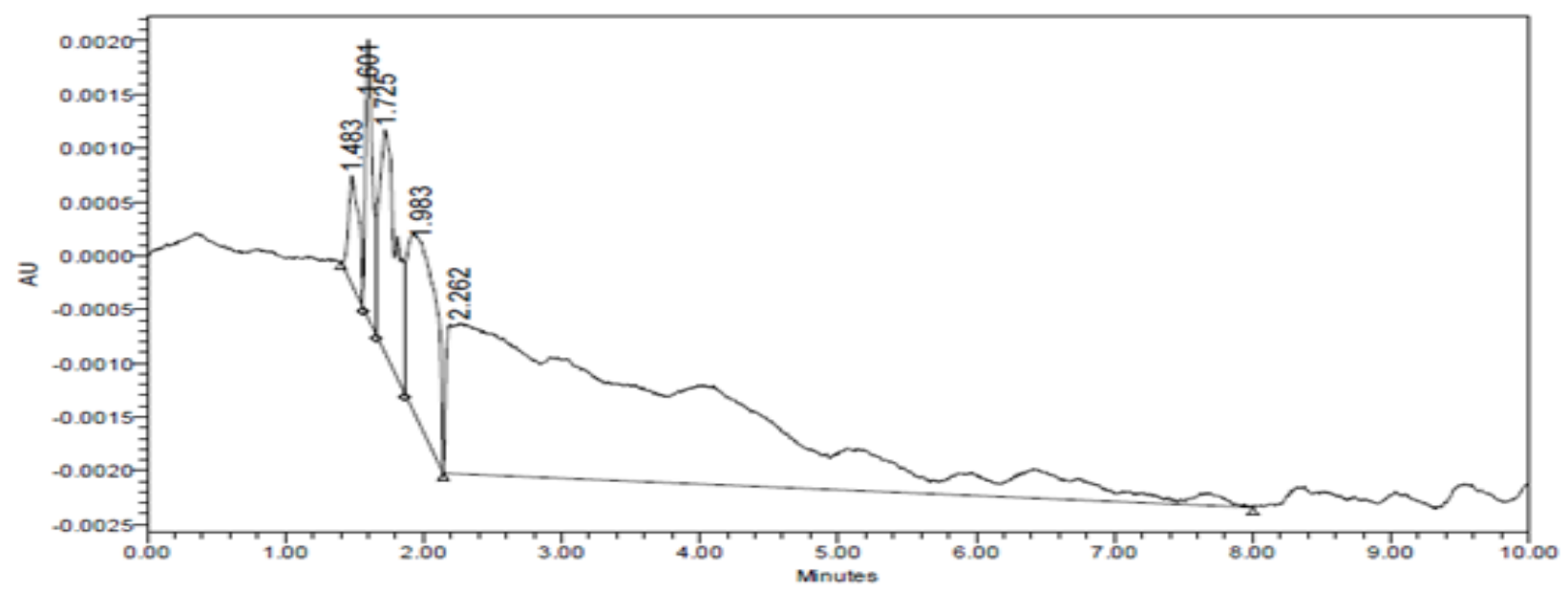

Fig. 6 (D) : Treated methyl orange at $1000 \mathrm{mgl}^{-1}$.

Table 1: GC-MS data for metabolites obtained after decolourization of methyl orange

\begin{tabular}{lll}
\hline Degradation intermediates & $\mathbf{t}_{\mathrm{R}}(\min )$ & $\mathbf{M}_{\mathbf{w}}$ \\
\hline 1,4-dimethylbenzen & 5.320 & 106.17 \\
N,N-dimethylhydrazine & 13.123 & 60.10 \\
4-tert-butylcyclohexanone & 17.703 & 154.52 \\
1,4,7,10,13-pentaoxacyclopentadecane & 44.755 & 220.26 \\
\hline
\end{tabular}

with S.grossus plants for 42 day (Fig. 4). The highest removal of BOD by plant was $55 \%$ for $400 \mathrm{mg} \mathrm{l}^{-1}$ dye and the lowest removal was $18 \%$ for $200 \mathrm{mgl}^{-1}$, while BOD removals were 40,38 and $40 \%$ for 600,800 and $1000 \mathrm{mg} \mathrm{I}^{-1}$ respectively. However, the BOD efficiency removal without plant were $12,44,30,13$ and $12 \%$ for $200,400,600,800$ and $1000 \mathrm{mg} \mathrm{l}^{-1}$. Similarly, the highest COD removal with plant was $52 \%$ for $400 \mathrm{mg} \mathrm{l}^{-1}$, while the lowest removal efficiency was $28 \%$ for $1000 \mathrm{mg} \mathrm{l}^{-1}$, while the COD removals were 35,39 and $29 \mathrm{mg} \mathrm{l}^{-1}$ for 200,600 and $800 \mathrm{mg} \mathrm{l}^{-1}$. The COD removal in the aquaria without plants was $3,18,33,11$ and $7 \%$ for $200,400,600,800$ and 1000 . The highest removal for TOC was $42 \%$ for $200 \mathrm{mgl}^{-1}$ while the lowest was $21 \%$ for $800 \mathrm{mgl}^{-1}$ and 33,23 and $24 \%$ for 400,600 and $1000 \mathrm{mgl}^{-1}$, however, without plant the removal efficiency was only $12,17,9,13$ and $10 \%$ for the same concentrations as depicted in Fig. 4. BOD, COD and TOC are widely studied parameters for determining organic matter in wastewater. The results of BOD, COD and TOC experiments indicated that the plant of $S$. grossus had significant impact on decolourisation of dye compared to the control aquariums without plants.

Fig. 5 illustrates the number of microbial populations in the rhizosphere zone of $S$. grosses at different concentrations of dye. The removal of dye depends on the abilities of microorganism in the surrounding rhizosphere (Zee et al., 2005).
Generally, decolourization of azo dyes occurs under conventional anaerobic, facultative anaerobic and aerobic conditions by different groups of bacteria. The microbial degradation strategies of azo dyes involves the reductive cleavage of azo bonds $(-\mathrm{N}=\mathrm{N}-)$ with the help of azoreductase enzymes under anaerobic conditions that led to the formation of colourless solutions containing potentially hazardous-aromatic amines (Jadhav et al. 2008; Radha and Asha 2016). Several studies were conducted to isolate microorganisms including rhizobacteria (Singha et al. 2017) and fungi (Singh et al., 2016) from the rhizosphere of plants, which can potentially promote the plant growth as well as degrade or detoxify pollutants inside wastewater or contaminated soil.

During experiment, microbial populations in the aquarium of dye concentration at $1000 \mathrm{mg} \mathrm{l}^{-1}$ were significantly lower than those in other aquaria. Sani et al. (1999); Saratale et al. (2009) suggested that increasing the dye concentration gradually decrease the decolourization rate, probably due to the toxic effect of dyes with regard to the individual bacteria. During exposure, microbial population at the control soil was $4.3 \times 10^{5} \mathrm{CFU} \mathrm{ml}^{-1}$ on

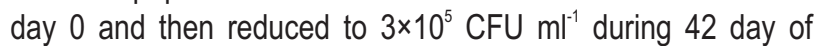
treatment. The bacterial population in the treatment with the lowest dye concentration of $200 \mathrm{mg} \mathrm{l}^{-1}$ amounted from $4.3 \times 10^{5}$ to $4.1 \times 10^{5} \mathrm{CFU} \mathrm{ml^{-1 }}$ during 42 days of treatment, which was higher 
than other dye concentrations. Generally, during the first 14 days, there was increment in the bacterial population at 400,600, 800 and $1000 \mathrm{mg} \mathrm{l}^{-1}$ dye concentration and then started to decrease until the end of 42 day period of exposure, except at $200 \mathrm{mg} \mathrm{l}^{-1}$ the bacteria population maintained until the end of treatment.

The HPLC analysis of untreated methyl orange at $200 \mathrm{mg}$ $\mathrm{I}^{-1}$ (Fig. 6A) showed peaks at 1.45,1.60, 1.62 and 3.13 min while treated methyl orange (Fig. 6B) showed peaks at 1.53, 1.60,1.72, 1.98 , and $2.21 \mathrm{~min}$, respectively. The peak obtained at the retention time of 1.60 min which was obtained in the HPLC analysis of both control sample, and the products formed after degradation indicated that it could represent some metabolites produced by the plant (Baiocchi et al., 2002).

Similarly, the HPLC analysis of untreated methyl orange at $1000 \mathrm{mg} \mathrm{l}^{-1}$ (Fig. 6C) showed peaks at 1.48,1.66 and $2.187 \mathrm{~min}$ while treated methyl orange (Fig. $6 \mathrm{D}$ ) showed speaks at 1.48 , $1.66,1.725,1.983$ and 2.26 min of which peaks at 1.48 and 1.66 min were corresponding to the root exudates of $S$. grossus. The methyl orange degradation of was confirmed by the disappearance of peaks before degradation and the formation of a new metabolite peaks with different Rt in the treated sample. The degradation products were further analyzed using GC/MS. Their GC retention times $\left(t_{R}\right)$, molecular weights $\left(M_{w}\right)$ and chemical structure are listed in Table 1. The detected intermediates were 1,4-dimethylbenzen, N, N-dimethyl hydrazine, 4-tert-butylcyclohexanone and 1,4,7,10,13Pentaoxacyclopentadecane.

This study shows the capability of $S$. grossus to decolorize methyl orange dye in different wastewater concentrations after 42 day in a batch free flow system. The highest dye removal of $64 \%$ was obtained at methyl orange dye concentrations of $200 \mathrm{mg} \mathrm{I}^{-1}$ giving evidence that $S$. grossus has the ability to degrade dye efficiently at lower dye concentrations.

\section{Acknowledgments}

The authors would like to thank Universiti Kebangsaan Malaysia (UKM) and the Tasik Chini Research Centre for supporting this research project through MI-2018-003.

\section{References}

Ahmad, J., S.R.S Abdullah, H.A. Hasan and M. Idris: Screening of tropical native aquatic plants for polishing pulp and paper mill final effluent. Ukm. My, 21,105-112(2017).

Al-Baldawi, I., S.R.S Abdullah, S.R.S. Anuar and M. Idris: Bioaugmentation for the enhancement of hydrocarbon phytoremediation by rhizobacteria consortium in pilot horizontal subsurface flow constructed wetlands. Int. J. Environ. Sci. Technol., 14, 75-8(2017).

Al-Baldawi, I., S.R.S. Abdullah, H.A. Hasan and N. Anuar: Phytotransformation of methylene blue from water using aquatic plant (Azolla pinnata). Environ. Technol. Innov., 11, 15-22 (2018).
Almaamary, E., S.R.S Abdullah, H.A. Hssan, R.A. Ab. Rahim and M. Idris: Treatment of methylene blue in wastewater using Scirpus grossus. Ukm. My, 21, 182-187 (2017).

Almansoory, A.F., M. Idris, S.R.S. Abdullah and N. Anuar: Phytoremediation of contaminated soils containing gasoline using Ludwigia octovalvis (Jacq.) in greenhouse pots. Environ. Sci. Poll. Res., 24, 11998-12008 (2017).

Al-Sbani, N.H., S.R.S. Abdullah, M. Idris, H. Abu Hasan, O.H. Jehawi and N.I. Ismail: Sub-surface flow system for PAHs removal in water using Lepironia articulate under greenhouse conditions. Ecol. Engg., 87, 1-8 (2016).

Anjaneyulu, Y., S. Chary and S.S. Raj: Decolourization of industrial effluents - Available methods and emerging technologies - A Review. Rev. Environ. Sci. Bio/Technol., 4, 245-273 (2005).

Baiocchi, C., M.C. Brussino, M.E. Pramauro, B. Alessandra and L. Palmisano: Characterization of methyl orange and its photocatalytic degradation products by HPLC/UV-VIS diode array and atmospheric pressure ionization quadrupole ion trap. Elsevier, 214, 247-256 (2002).

Barman, M. and S.B. Datta. Assessing phtytoxic limits of nickel in intensively cultivated alluvial soils. J. Environ. Biol., 39, 358-364 (2018).

Cássia, M.R. de., E. de B. Gomes, N. Pereira. Jr. M.P. Marin Morales and K.M.G. Machado: Biotreatment of textile effluent in static bioreactor by Curvularia lunata URM 6179 and Phanerochaete chrysosporium URM 6181. Elsevier, 142, 361-367 (2013).

Chang, J. and T. Kuo: Kinetics of bacterial decolorization of azo dye with Escherichia coli NO3. Elsevier, 75, 107-111(2000).

Ismail, N. 'Izzati, S.R.S. Abdullah, M. Idris, H.A. Hasan, M.I.E. Halmi, N.H. AL Sbani and O.H. Jehawi: Accumulation of Fe-Al by Scirpus grossus grown in synthetic bauxite mining wastewater and identification of resistant rhizobacteria. Environ. Engg. Sci., 34, 367-375(2017).

Jadhav, S. and M. Jadhav: Decolorization of Brilliant Blue $G$ dye mediated by degradation of the microbial consortium of Galactomyces geotrichum and Bacillus sp. Elsevier, 39, 563-570 (2008).

Kabra, A.N., R.V. Khandare and S.P. Govindwar: Development of a bioreactor for remediation of textile effluent and dye mixture: A plant-bacterial synergistic strategy. Water Res., 47, 1035-48 (2013).

Kagalkar, A., U. Jagtap, J. Jadhav and S.G. Planta: Studies on phytoremediation potentiality of Typhonium flagelli form for the degradation of Brilliant Blue R. Springer, 232, 271-285 (2010).

Khandare, R.V. and S.P. Govindwar: Phytoremediation of textile dyes and effluents: Current scenario and future prospects. BiotechnologyAdvances, 33, 1697-1714 (2015).

Khandare, R.V., A.N. Kabra, D.P. Tamboli and S.P. Govindwar: The role of Aster amellus Linn. in the degradation of a sulfonated azo dye Remazol Red: A phytoremediation strategy. Chemosphere, 82, 1147-54 (2011a).

Khandare, R.V., A.N. Kabra, D.P. Tamboli and S.P. Govindwar: Degradation of methyl orange an azo dye by: A phytoremediation strategy. Chemosphere, 82, 1147-54(2011b).

Khandare, R.V., A. N.Kabra, M.B. Kurade and S.P. Govindwar: Phytoremediation potential of Portulaca grandiflora Hook. (MossRose) in degrading a sulfonated diazo reactive dye Navy Blue HE2R (Reactive Blue 172). Biores. Technol., 102, 6774-6777 (2011). 
Khataee, A.R., A. Movafeghi, S. Torbati, S.Y. Salehi Lisar and M. Zarei: Phytoremediation potential of duckweed (Lemna minor L.) in degradation of C.I. Acid Blue 92: Artificial neural network modeling. Ecotoxicol. Environ. Saf., 80, 291-8 (2012).

Lin, Q. and I.A. Mendelssoohn: Potential of restoration and phytoremediation with Juncus roemerianus for dieselcontaminated coastal wetlands. Elsevier, 35, 85-91 (2000).

Mandal, S.K. and N. Das: Phyto-mycoremediation of benzo[a]pyrene in soil by combining the role of yeast consortium and sunflower plant. J. Environ. Biol., 39, 261-268 (2018).

Miranda, A.F., B. Biswas, N. Ramkumar, R. Singh, J. Kumar, A. James and F. Roddick: Biotechnology for biofuels aquatic plant Azolla as the universal feedstock for biofuel production. Biotechnol. Biof., 9 , 1-17 (2016).

Pi, K., Q. Xiao, H. Zhang M. Xia and A.R. Gerson: Decolorization of synthetic methyl orange wastewater by electrocoagulation with periodic reversal of electrodes and optimization by RSM. Process Saf. Environ. Protect., 92, 796-806 (2014).

Radha, R. and J. Asha: Influence of insecticide phorate on chemical composition and enzyme profile of root exudates and root extracts of Brassica juncea. J. Environ. Biol., 37, 413-419 (2016).

Rane, N. and V. Chandanshive: Green remediation of textile dyes containing wastewater by Ipomoea hederifolia L. RSC Adv., 4, 36623-36632 (2014).

Sani, R. and U. Banerjee: Decolorization of triphenylmethane dyes and textile and dye-stuff effluent by Kurthia sp. Elsevier, 24, 433-437 (1999).

Sanusi, S.N.A., M.I.E. Halmi, S.R.S. Abdullah, H. Abu Hassan, F.M. Hamzah and M. Idris: Comparative process optimization of pilot scale total petroleum hydrocarbon (TPH) degradation by Paspalum scrobiculatum L. hack using response surface methodology (RSM) and artificial neural network (ANN). Ecol. Engg., 97, 524-534 (2016).

Saratale, R. and G. Saratale: Ecofriendly degradation of sulfonated diazo dye $\mathrm{Cl}$ Reactive Green 19A using Micrococcus glutamicus NCIM2168. Elsevier, 100, 3997-3905(2009).

Selamat, S.N., M.I.E. Halmi, S.R.S. Abdullah, M. Idris, H. Abu Hassan and $\mathrm{N}$. Anuar: Optimization of lead $(\mathrm{Pb})$ bioaccumulation in Melastoma malabathricum $\mathrm{L}$. by response surface methodology (RSM). Rendiconti Lincei - Scie. Fisiche-e Naturali, 29, 43-51 (2018)

Singh, G., S. Pankaj and S. Suneyana: Role of growth media on the phytopromotional potential of symbiotic fungus Piriformospora indica. J. Environ. Biol., 37, 889-894 (2016).

Singha, B., P.B. Mazumder and P. Pandey: Characterization of plant growth promoting rhizobia from root nodule of Mimosa pudica grown in Assam, India. J. Environ. Biol., 38, 441-447 (2017).

Sieuwerts, S., F.A.M. de Bok, E. Mols, W.M. de Vos and J.E.T. van Hylckama Vlieg: A simple and fast method for determining colony forming units. Lett. Appl. Microbiol., 47, 275-278 (2008).

Tangahu, B.V., S.R.S. Abdullah, H. Basri, M. Idris, N. Anuar and M. Mukhlisin: Phytotoxicity of wastewater containing lead $(\mathrm{Pb})$ effects Scirpus grossus. Int. J. Phytorem., 15, 814-826 (2013).

Telke, A.A., A.N. Kagalkar, U.B. Jagtap, N.S. Desai, V.A. Bapat and S.P. Govindwar: Biochemical characterization of laccase from hairy root culture of Brassica juncea L. and role of redox mediators to enhance its potential for the decolorization of textile dyes. Planta, 234, 1137-1149 (2011)

Venkata, M.S., N.C. Rao and J. Karthikeyan: Adsorptive removal of direct azo dye from aqueous phase onto coal based sorbents: A kinetic and mechanistic study. J. Hazar. Mat., 90, 189-204 (2002).

Vymazal, J.: Constructed wetlands for wastewater treatment: A review. Water, 2, 965-980 (2008)

Watharkar, A.D.A., N.R.N. Rane and S.S.M. Patil, R.V. Khandare and J. P. Jadhav: Enhanced phytotransformation of Navy Blue RX dye by Petunia grandiflora Juss. with augmentation of rhizospheric Bacillus pumilus strain $\mathrm{PgJ}$ and subsequent toxicity analysis. Biores. Technol., 142, 246-254 (2013).

Winkler, L.W.: Die Bestimmung des in Wasser gelösten Sauerstoffen. Berichte der Deutschen Chemischen Gesellschaft, 21, 28432855, (1888).

Zee, F. Van der and S. Villaverde: Combined anaerobic-aerobic treatment of azo dyes-a short review of bioreactor studies. Elsevier, 39, 1425-1440(2005). 